\title{
Impact of Reel Index on Header Losses of Paddy and Performance of Combine Harvesters
}

\author{
R. Bawatharani ${ }^{*}$, D.N. Jayatissa ${ }^{1}$ D.A.N. Dharmasena ${ }^{1}$ and M.H.M.A. Bandara ${ }^{2}$ \\ Postgraduate Institute of Agriculture \\ University of Peradeniya \\ Sri Lanka
}

\begin{abstract}
This study investigated the effect of reel index and type of combine harvester on header losses when harvesting the long grain paddy variety Bg 94-1. The field experiment was carried out in a split plot design with three replicates. Two brands of popular combine harvesters (Kubota ${ }^{\circledR}$ DC-68G and Agroworld ${ }^{\circledR} 4 L-88$ ) and three levels of reel index i.e. 1.2, 1.7 and 2.5, were assigned to the main plots and sub plots, respectively. The results revealed a greater header advancement and an increased tine bar velocity at the reel index of 1.2 resulting in a higher header losses in both combine harvesters. Similarly, lesser header advancement and increased number of impacts of the reel on panicles at the reel index of 2.5 also caused greater header losses. The reel index of 1.7 resulted in significantly low header losses of 38.8 and $45.8 \mathrm{~kg} / \mathrm{ha}$ from Kubota and Agroworld ${ }^{\circledR}$ harvesters, respectively. The performance evaluation revealed that Kubota combine harvester had relatively higher field capacities and field efficiencies at all three reel indices when compared to Agroworld ${ }^{\circledR}$ machine. The field capacities decreased from 0.380 to 0.245 ha/h for Kubota and from 0.197 to $0.175 \mathrm{ha} / \mathrm{h}$ for Agroworld ${ }^{\circledR}$ combine harvesters across the reel indices 1.2 to 2.5. The field efficiencies increased from 49.3 to $60.9 \%$ and 30.6 to 50.8\% across the reel indices 1.2 to 2.5 for Kubota and Agroworld ${ }^{\circledR}$ harvesters, respectively. In general, a reel index of 1.7 would be the ideal for minimum header losses as well as an acceptable field capacity and field efficiency for both types of combine harvesters.
\end{abstract}

Keywords: Combine harvester, field capacity, field efficiency, header loss, reel index

\section{INTRODUCTION}

Batticaloa district in the Eastern Province of Sri Lanka is heavily dependent on agriculture for its economic survival. The majority of the population is engaged in paddy production and approximately 58,374 hectares are under paddy cultivation. Recently, paddy harvesting has become a serious problem for farmers in Batticaloa due to shortage of labour. In order to overcome this situation, farmers in the large scale paddy growing areas have employed combine harvesters. Therefore, there was a rapid increase in the use of combine harvesters in the recent past.

However, the combine harvesters cause negative impacts on the quantity and the quality of paddy grains which seriously affect the profitability of the crop (Hashish, 1984; Hassan et

\footnotetext{
Department of Agricultural Engineering, Faculty of Agriculture, University of Peradeniya, Sri Lanka

Chief Engineer's Office, Department of Agriculture, Peradeniya, Sri Lanka

Corresponding author: bavatharani@yahoo.com.sg
} 
al., 1994; Helmy et al., 1995). Most of the losses are caused by improper adjustment of the machines with respect to crop conditions or due to improper machine speeds (Griffin, 1976). Considering the importance of grain loss in the header unit of the combine harvester, the amount of loss and causes of losses must be scientifically investigated through proper adjustment of operating conditions. According to the previous research work on this subject, the influence of forward speed and the rotational speed of the reel on paddy loss during harvesting need to be investigated carefully (Griffin, 1976; El-Shal \& Morad, 1991).

Consequently, selection of optimum conditions to harvest paddy and the improvement of combine performance during harvesting are vital steps towards the augmentation of the net availability of paddy grains to recover better yield through minimization of header losses. Nevertheless, there are only a few studies (Mahrouf \& Rafeek, 2010; Samaraweera, 2012) conducted focusing on the factors influencing the operation of paddy combine harvesters in Sri Lanka.

This investigation aimed to compare two popular combine harvesters in terms of grain losses and their performance for recommending appropriate machine conditions to harvest paddy based on critical technical parameters. Therefore, the objectives of the study were to measure the header grain losses from two different brands of combine harvesters (Kubota ${ }^{\circledR} D C-68 G$ and Agroworld ${ }^{\circledR} 4 L-88$ ) as influenced by three levels of reel indices and to compare the performance of those combine harvesters.

\section{METHODOLOGY}

\section{Study area}

The field test was conducted at Palugamam in the Batticaloa district of Sri Lanka. BG 94-1, a long grain paddy variety was planted in a $450 \mathrm{~m} \times 20 \mathrm{~m}$ field and cultivated according to the usual practices of the farmers. The experiment was conducted in a $2 \times 3$ split plot design with six treatment combinations and three replicates. The experimental treatments were three levels of reel indices; 1.2, 1.7 and 2.5, and two brands of combine harvesters (Table 1). The machine type was assigned as the main plot factor whereas the reel indices were assigned as sub-plot factors.

Table 1. Functional specification of header unit factors and the relevant reel indices.

\begin{tabular}{ccccc}
\hline $\begin{array}{c}\text { Brand of combine } \\
\text { harvester }\end{array}$ & \multicolumn{5}{l}{} \\
\hline & $\begin{array}{l}\text { Forward } \\
\text { speed }(\mathrm{m} / \mathrm{s})\end{array}$ & $\begin{array}{c}\text { Reel rotational } \\
\text { speed }(\mathrm{rad} / \mathrm{s})\end{array}$ & $\begin{array}{c}\text { Reel radius } \\
(\mathrm{m})\end{array}$ & $\begin{array}{c}\text { Approximate } \\
\text { reel index }\end{array}$ \\
\cline { 2 - 5 } Kubota $D C-68 G$ & 1.18 & 3.15 & 0.45 & 1.2 \\
& 0.82 & 3.15 & 0.45 & 1.7 \\
& 0.56 & 3.15 & 0.45 & 2.5 \\
\hline \multirow{2}{*}{ Agroworld4L-88 } & 1.06 & 3.15 & 0.43 & 1.2 \\
& 0.76 & 3.15 & 0.43 & 1.7 \\
\hline
\end{tabular}

The Kubota $D C-68 G$ harvester of Japanese origin is fitted with a $49.3 \mathrm{~kW}$ diesel engine and the Agroworld $4 L-88$ harvester of Chinese origin is fitted with a $52.94 \mathrm{~kW}$ diesel engine. 
Both combine harvesters were crawler type with a $2 \mathrm{~m}$ cutting width. All the field trials were conducted according to RNAM test code (RNAM Test Codes, 1995).

\section{Measurement of crop and machine operating parameters}

To understand the machine operating conditions, the selected crop and machine parameters were determined using the methods given in Table 2.

Table 2. Methods employed in the analysis of crop and machine parameters.

\begin{tabular}{ll}
\hline Parameter & Method of analysis \\
\hline Grain moisture content & 'Satake' grain moisture meter \\
Reel rotational velocity & Stop watch and counter \\
Reel radius & Measuring tape (steel) \\
Cutter bar pulley speed & Tachometer (HIOKI 3404, Japan) \\
Speed of combine harvester & Stop watch and measuring tape \\
Height of cutter bar & Measuring tape (steel) \\
Height of the reel axis above the ground & Measuring tape (steel) \\
\hline
\end{tabular}

\section{Measurement of grain yield and pre-harvest losses}

Grain yield was determined by throwing a quadrate made of stiff steel measuring $0.71 \mathrm{~m} \mathrm{x}$ $0.71 \mathrm{~m}\left(0.5 \mathrm{~m}^{2}\right)$ area and harvesting the panicles enclosed in this area using a sickle. Preharvest losses were determined by placing the quadrate at five randomly selected places in each plot before the combine harvester entered the plots. Loose grains and panicles fallen on the ground were collected within the quadrate and weighed after drying.

\section{Definition of operational parameters of combine harvester}

The operational parameters of the combine harvester are defined based on Fig. 1.

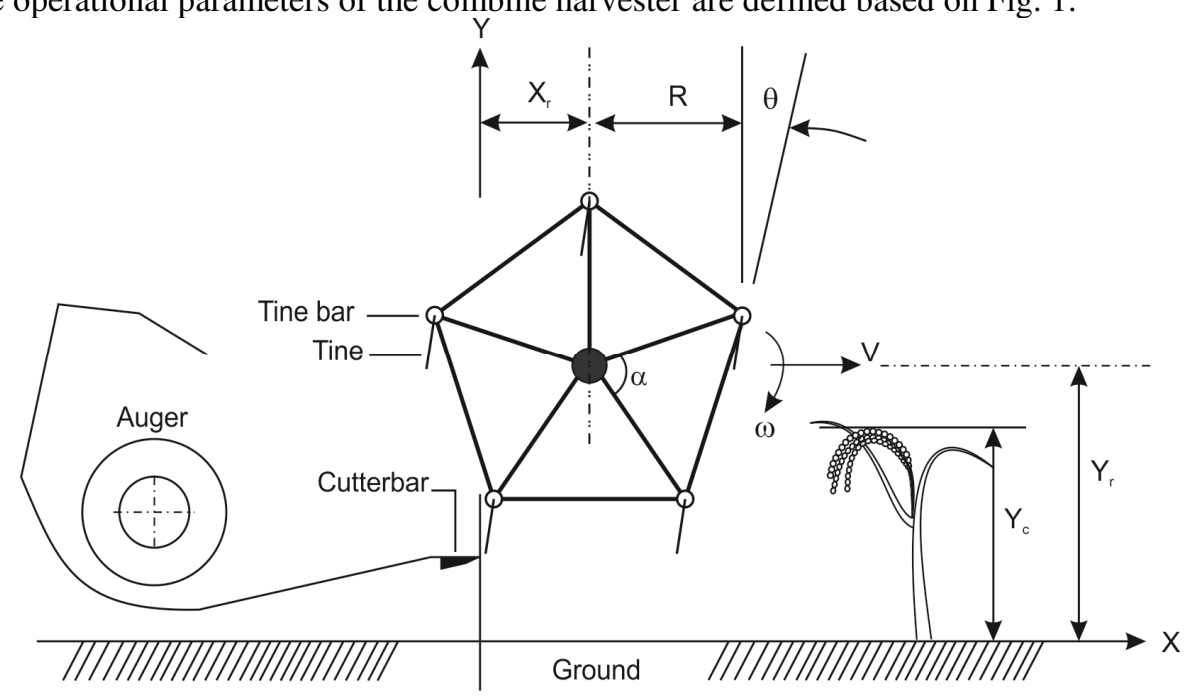

Fig. 1. The combine harvester reel and the parameters that are relevant to the analysis of its motion (modified from Oduori et al., 2012). 


\section{Reel index}

Reel index was determined using Equation 1 as reported by Oduori et al., 2012.

$$
K=\frac{w R}{v}
$$

where,

$\mathrm{K}$ - Reel index (dimensionless)

$\omega-$ Angular velocity of reel $(\mathrm{rad} / \mathrm{s})$

$\mathrm{R}$ - Radius of reel (m)

$v$ - Header advance velocity $(\mathrm{m} / \mathrm{s})$

\section{Header advance $\left(\mathbf{R}_{0}\right)$}

The header advance (reel advance) per radian of reel rotation was determined using Equation 2 (Oduoriet al., 2012).

where,

$$
\mathrm{R}_{0}=\mathrm{V} / \omega
$$

$V$ - Header advance velocity $(\mathrm{m} / \mathrm{s})$

$\omega$ - Angular velocity of reel ( $\mathrm{rad} / \mathrm{s})$

$R_{0}-$ Header advance per radian of reel rotation (m)

\section{Tine bar velocity at impact with the panicle}

The tine bar velocity when it impacts with the panicle is given by Equation 3 and 4 (Oduori et al., 2008).

$$
U_{i}=V \sqrt{1+2\left(\frac{Y_{i}-Y_{Y}}{B_{0}}\right)+\left(\frac{A}{B_{0}}\right)^{2}}
$$

where,

$$
Y_{i}=Y_{r}+R \cos \omega t_{i}
$$

$U_{i-}$ Velocity of tine bar at impact with the panicle $(\mathrm{m} / \mathrm{s})$

$Y_{r^{-}}$Height of the reel axis above the ground (m)

$Y_{i}$ Height of the point of impact between tine bar and the panicle (m)

$\mathrm{t}_{\mathrm{i}}-$ Time at the moment of impact (s)

\section{Number of impacts between tine bars and the panicles}

In a time duration denoted by $t$, the header advance distance is $V t(\mathrm{~m})$, the angle of reel rotation is at (rad) and the number of crop-tine bar impact is $\frac{a t}{a}$. Therefore, for a unit distance of a metre of header advance, the number of crop-tine bar impacts is given by Equation 5 (Oduori et al., 2008).

$$
n_{i}=\frac{\omega t}{\alpha, V, t}=\frac{1}{\alpha n_{0}}
$$


where,

$n_{i}-$ Number of tine bars - panicle impacts per metre of header advance $\left(\mathrm{m}^{-1}\right)$

$\mathrm{t}-$ An arbitrary time interval (s)

$\alpha$ - Angle between successive tine bars (rad)

\section{Measurement of header losses}

The combine harvesters were allowed to move forward for about $20 \mathrm{~m}(1 \mathrm{~m}$ from the border of each experimental plot) to attain a steady state speed and it was suddenly stopped. The header unit was lifted up and the machine was moved back for about $5 \mathrm{~m}$. The quadrate mentioned earlier was placed in front of the parked machine and the grains and panicles were manually collected. The panicles were then manually threshed and the header losses were determined by weighing the fallen grains and collected panicle-grains. The samples for header loss were collected in four replicates in each experimental plot.

\section{Performance evaluation}

\section{Effective field capacity $(S)$}

Time consumed for real harvesting and that lost for unproductive activities were used to calculate the effective field capacity based on Equation 6 . The unproductive time elements included the time lost for turning the machine, unloading the grain tank, rearranging the grain tank, removal of straw clogging and other idle times during harvesting.

$$
S=\frac{A}{T_{p}+T_{1}}
$$

where,

$S$ - Effective field capacity (ha/h)

$A$ - Area covered (ha)

$T_{p}$ - Productive time (h)

$T_{l}$ - Unproductive time (h)

\section{Field efficiency $\left(E_{f}\right)$}

It was calculated from the test data as the ratio of productive time to the total time using Equation 7.

$$
E_{f}=\frac{r_{p}}{T_{p}+T_{1}} \ldots \ldots \ldots \ldots \ldots \ldots
$$

\section{Statistical analysis of data}

Data obtained from the field were analyzed with regard to header loss, combine capacity and field efficiency using SAS version 9.1. The significance of interaction between combine type and the reel index on header losses, combine capacity and field efficiency were evaluated at 0.05 probability level through Duncan Multiple Range Test (DMRT). 


\section{RESULTS AND DISCUSSION}

\section{Effect of reel index}

The relationship between header loss and reel index tends to produce a quadratic curve, which clearly depicts that the header loss would be the least at the vertex of the parabolic curve. When the reel index was increased, the losses were found to be low at the beginning. However, at higher reel index values there was a tendency to increase losses (Fig. 2), which was in accordance with the study by Chinsuwan et al. (2004) and Sial et al. (1992).The lowest reel index value of 1.2 and the highest reel index value of 2.5 resulted in more losses in this study. Header losses from both combine harvesters were found to decline from reel indices 1.2 to 1.7 , but there was a tendency for the header losses to be higher when the reel index was less than 1.2 or greater than 2.5 . However, this observation would hold good only for the factors considered in this experiment.

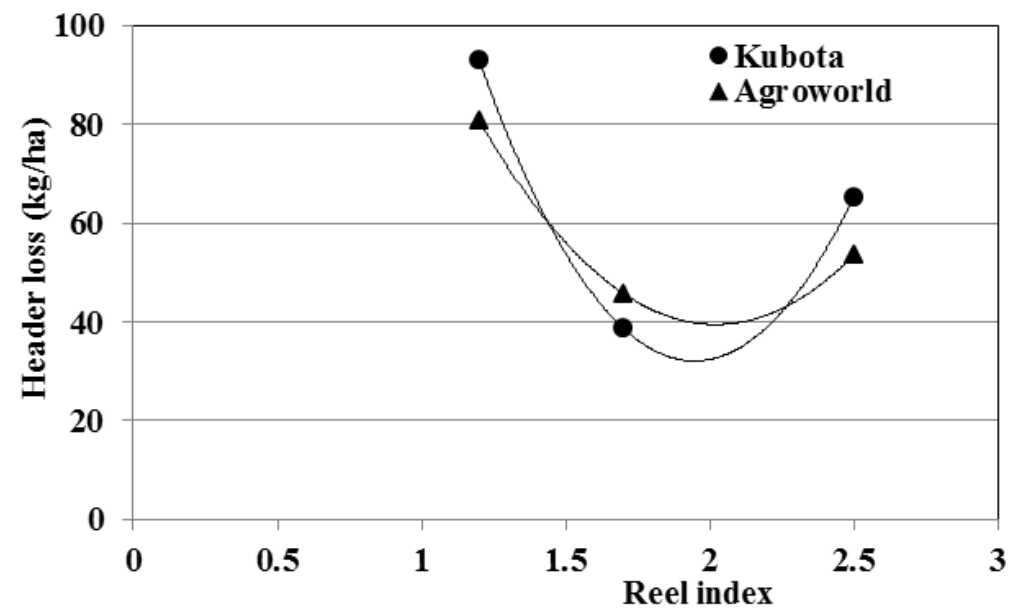

Fig. 2. Header losses at different reel index levels.

The header advancement was calculated and tabulated at a constant height of $1.1 \mathrm{~m}$ of the reel axis above the ground with reference to the crop height of $82 \mathrm{~cm}$ for both types of combine harvesters (Table 3). Since the reel is part of the header unit, the header advancement is identical to the reel advancement. The header advancement of $0.374 \mathrm{~m}$ and $0.336 \mathrm{~m}$ for Kubota and Agroworld at reel index of 1.2 implies the lowest crop gathering capacity (Table 3). At lower reel index values, the combine harvesters moved quickly irrespective of the constant rotational speed of the reel so that the header advance per radian of reel rotation was greater, which in turn resulted in higher header losses. This could be due to the reel failing to grab panicles (i.e. gathers smaller quantity of panicles per cycle of its motion) at lower reel index (i.e. higher forward speeds) and caused much trouble due to clogging, which was prominent in the Agroworld combine harvester. 
Table 3. Header advancement per radian of reel rotation and the number of impacts.

\begin{tabular}{ccccccc}
\hline \multirow{2}{*}{$\begin{array}{c}\text { Reel } \\
\text { Index }\end{array}$} & \multicolumn{6}{c}{ Kubota $^{\circledR} D C-68 G$} \\
\cline { 2 - 7 } & $\begin{array}{c}\text { Header } \\
\text { advance }\left(\mathrm{R}_{0}\right) \\
(\mathrm{m})\end{array}$ & $\begin{array}{c}\text { No. of } \\
\text { impacts }\end{array}$ & $\begin{array}{c}\text { Tine bar } \\
\text { velocity } \\
(\mathrm{m} / \mathrm{s})\end{array}$ & $\begin{array}{c}\text { Header } \\
\text { advance }\left(\mathrm{R}_{0}\right) \\
(\mathrm{m})\end{array}$ & $\begin{array}{c}\text { No. of } \\
\text { impacts }\end{array}$ & $\begin{array}{c}\text { Tine bar } \\
\text { velocity } \\
(\mathrm{m} / \mathrm{s})\end{array}$ \\
\hline 1.2 & 0.374 & 2 & 2.51 & 0.336 & 2 & 2.33 \\
1.7 & 0.260 & 3 & 2.16 & 0.241 & 3 & 2.04 \\
2.5 & 0.177 & 4 & 1.92 & 0.168 & 5 & 1.83 \\
\hline
\end{tabular}

Moreover, when the header advancement of $0.177 \mathrm{~m}$ and $0.168 \mathrm{~m}$ with Kubota and Agroworld, respectively at the reel index of 2.5 indicates that the reel rotates with less advancement into the crop and increased the amount of panicles gathered by the reel in a single cycle of its rotation. However, the number of impacts caused to the panicles was higher so that the tines hit the panicles harshly, increasing losses. It was also observed that the reel-crop impact was different at each reel index because the number of impacts per unit distance of reel advance is inversely proportional to the header advance per radian of reel rotation (Oduori et al., 2008). These observations were consistent with the results obtained by Chinsuwan et al. (1997), who reported that when the reel index was low, the tine failed to sweep all the paddy towards the header. On the other hand, when the reel index was high, the tine would beat the panicles violently resulting in greater loss.

The header losses from Kubota and Agroworld were $38.8 \mathrm{~kg} / \mathrm{ha}$ and $45.8 \mathrm{~kg} / \mathrm{ha}$ at a reel index of 1.7. However, the total losses were higher for Agroworld than that of Kubota at this reel index. The reason is that the Agroworld combine harvester experienced clogging of panicles in the header unit even at the reel index of 1.7. All these observations suggest that the reel gathers comparatively smaller quantity of panicles per cycle of its rotation at a reel index of 1.2, which implies larger values of reel index might be favourable to maximize the rate of gathering of the panicles. However, it has been shown from this study that larger reel index levels, beyond 1.7 were also inappropriate, as far as the associated higher header losses are concerned. Oduori et al. (2012) have reported that the suitable value of reel index should vary with the crop and crop conditions and recommended reel index values lower than 1.5. However, Junsiri \& Chinusuwan (2009) found that the header losses were less when the reel index was between 1.5 to 3.0 and when the reel index was lower than 1.5 or greater than 3.0, there was a tendency for the header losses to be greater. Hence, the reel index should be increased with respect to its effect on grain losses.

\section{Magnitude of tine bar impact velocity with reel index}

Since the reel is rigid and power driven and the crop is much compliant, the reel-crop impact could also be attributed to the header losses. It has been found that the tine bar impact velocity was at its highest value of $2.51 \mathrm{~m} / \mathrm{s}$ at the reel index 1.2 for Kubota, whereas it was $2.33 \mathrm{~m} / \mathrm{s}$ for Agroworld and there was a decreasing trend of impact velocity with respect to the increase in reel index (Fig. 3). Therefore, the variation in header loss would be due to variation in magnitude of impact velocity at different reel indices. 


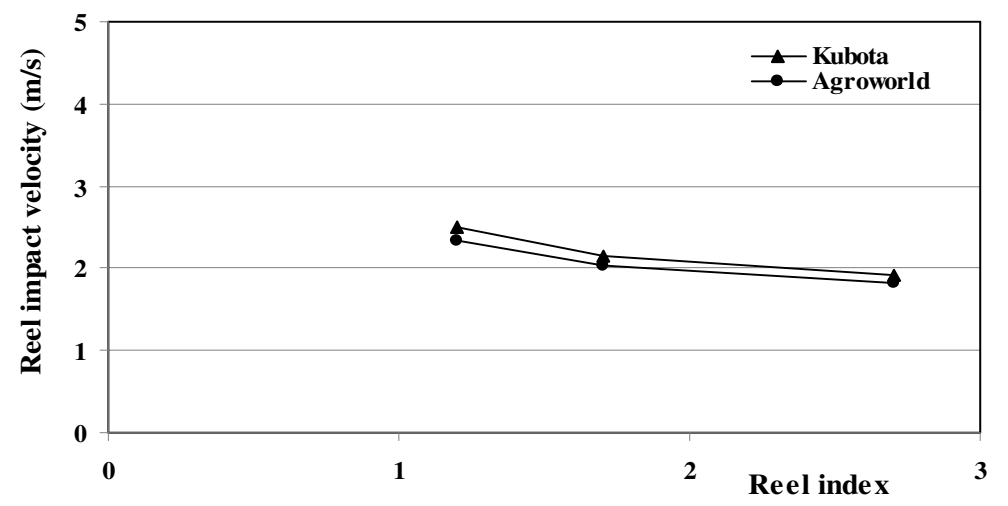

Fig. 3. Relationship between tine bar velocity and reel index.

Highest impact velocity at the reel index of 1.2 could be correlated with the highest header losses in both combine harvesters. However, the reel index of 2.5 resulted in impact velocities of $1.92 \mathrm{~m} / \mathrm{s}$ and $1.83 \mathrm{~m} / \mathrm{s}$ in Kubota and Agroworld, respectively, which were comparatively lower than impact velocities at the reel index of 1.2. But, the associated higher losses at these impact velocities were due to the increased number of impacts at the reel index of 2.5 (Table 3).

In the analysis of tined reel kinematics, it has been postulated that at the values of direction of tine bar velocities at 0 and $2 \pi$ radians $\left(360^{\circ}\right)$ of reel rotation, the tine bar strikes the crop with a velocity directed away from the crop. Added to that, the value of direction of tine bar velocity at $3 \pi / 2$ radians $\left(270^{\circ}\right)$ occurs at the lowest path of the tine bar, which implies that the tine bar does not enter the crop at all. i.e., this is not the likely point at which the tine bar strikes the crop (Oduori et al., 2012). But, the tine bar may strike the crop at $\pi$ radians $\left(180^{\circ}\right.$ ) of tine bar velocity and in such situation the shattering or header losses are mainly due to the impact velocity of the tine bar (Oduori et al., 2008). This implies that as long as the direction of impact velocity remains unchanged, any variation in header losses would be due to the variation of magnitude of the impact velocity only. Therefore, the tine bar should be made to enter the crop with its velocity vector directed in the negative Y direction (Goryachkin, 1974).

Therefore, minimization of losses should involve the manipulation of both the magnitude and the direction of tine bar velocity (Oduori et al., 2008; Oduori, 1994). Since the present investigation did not involve in the variation of direction of velocity of tine bar entry into the crop for various values of reel index, the effect of reel index on header losses under certain operating conditions is an area which needs further studies through kinematic analysis as well as empirical investigations.

\section{Evaluation of Field Performance}

\section{Effective field capacity}

Even though the effective field capacity decreased, the field efficiency increased with the increase in reel index for both types of combine harvesters (Table 4). The increasing reel indices of Kubota and Agroworld from 1.2 to 2.5 decreased the actual field capacities from $0.380 \mathrm{ha} / \mathrm{h}$ to $0.245 \mathrm{ha} / \mathrm{h}$ and from $0.197 \mathrm{ha} / \mathrm{h}$ to $0.175 \mathrm{ha} / \mathrm{h}$, respectively. Due to higher 
unproductive (idle) time at all the reel indices, Agroworld showed a relatively lower field capacity than Kubota. The effective field capacity of Kubota was found to be greater, due to less time taken to harvest the plots which was related to its stepless movement of the Hydro Static Transmission (HST) system under higher forward speeds.

\section{Field efficiency}

Increasing the reel index of Kubota from 1.2 to 2.5 increased the field efficiency from 49.3\% to $60.9 \%$, whereas for Agroworld, it increased from $30.6 \%$ to $50.8 \%$. Kubota had comparatively higher field efficiency at all the reel indices than Agroworld as switching the direction of movement between forward and reverse was easily accomplished in Kubota without the use of a clutch so that operations continued smoothly without interruption. Moreover, Kubota had the reverse processing mechanism lever, which enabled easy and efficient reverse movements of the reel in the cutting and conveying stages and therefore unclogging took place with utmost ease with less time requirement. But, this reverse mechanism in reel rotation is absent in Agroworld, and every time the clogged panicles had to be removed manually after stopping the machine, which increased the idling time leading to poor field efficiencies. Small sized plots $\left(45 \times 10 \mathrm{~m}^{2}\right)$ used in this study also contributed to the lower field efficiencies due to increased time losses. In general, the performance of the Kubota was found to be acceptable.

Table 4. Field performance of Kubota and Agroworld combine harvesters.

\begin{tabular}{|c|c|c|c|c|c|c|}
\hline \multirow{3}{*}{ Parameter } & \multicolumn{6}{|c|}{ Reel index } \\
\hline & \multicolumn{3}{|c|}{ Kubota } & \multicolumn{3}{|c|}{ Agroworld } \\
\hline & 1.2 & 1.7 & 2.5 & 1.2 & 1.7 & 2.5 \\
\hline Average speed $(\mathrm{km} / \mathrm{h})$ & 4.24 & 2.95 & 2.01 & 3.81 & 2.73 & 1.90 \\
\hline Width of cutter bar (m) & 2 & 2 & 2 & 2 & 2 & 2 \\
\hline Area of plot harvested (ha)* & 0.045 & 0.045 & 0.045 & 0.045 & 0.045 & 0.045 \\
\hline Total harvested time (min) & 7.1 & 8.3 & 11.0 & 13.7 & 14.1 & 16.7 \\
\hline Actual harvested time (min) & 3.5 & 4.9 & 6.7 & 4.2 & 6.0 & 8.5 \\
\hline Effective field capacity (ha/h) & 0.380 & 0.325 & 0.245 & 0.197 & 0.191 & 0.175 \\
\hline Theoretical field capacity (ha/h) & 0.840 & 0.600 & 0.408 & 0.708 & 0.504 & 0.336 \\
\hline Field efficiency $(\%)$ & 49.3 & 59.0 & 60.9 & 30.6 & 42.5 & 50.8 \\
\hline
\end{tabular}

\section{Statistical analysis}

\section{Header loss}

Header loss was significantly influenced by the reel index and the combine harvester type (Table 5). The header losses were significantly $(\mathrm{P}<0.05)$ different among the three levels of reel indices in Kubota, while the losses at the reel index of 1.7 were significantly lower than that of 1.2 and 2.5. In contrast, the header losses were significantly higher at reel index of 1.2 in Agroworld, whereas there were no significant differences between the reel indices 1.7 and 2.5 with regard to header losses (Table 6). 
Table 5. ANOVA of header losses.

\begin{tabular}{lccccc}
\hline \multicolumn{1}{c}{ Source } & $\begin{array}{c}\text { Sums of } \\
\text { squares }\end{array}$ & $\begin{array}{c}\text { Degrees of } \\
\text { freedom }\end{array}$ & $\begin{array}{c}\text { Means } \\
\text { square }\end{array}$ & F value & P value \\
\hline Replicate & 338.35 & 2 & 169.17 & 9.83 & 0.007 \\
Combine type (CT) & 142.8 & 1 & 142.80 & 8.30 & 0.02 \\
Reel index (RI) & 6072.88 & 2 & 3036.44 & 176.46 & $<0.0001$ \\
CT x RI & 361.12 & 2 & 180.56 & 10.49 & 0.0058 \\
\hline
\end{tabular}

Table 6. Effect of combine type and reel index on header losses.

\begin{tabular}{lcc}
\hline Combine type & Reel index & Mean loss (kg/ha) \\
\hline \multirow{3}{*}{ Kubota } & 1.2 & $92.96^{\mathrm{a}}$ \\
& 2.5 & $65.33^{\mathrm{b}}$ \\
\multirow{3}{*}{ Agroworld } & 1.7 & $38.76^{\mathrm{c}}$ \\
& 1.2 & $80.80^{\mathrm{a}}$ \\
& 2.5 & $53.56^{\mathrm{b}}$ \\
\hline
\end{tabular}

Means denoted by the same letter are not significantly different at $P=0.05$.

This finding clearly indicates that at the reel index of 1.7, the loss of grains was significantly $(\mathrm{P}<0.05)$ minimum when compared to other two levels of reel indices. Therefore, the effect of reel index on header losses was significantly influenced by the machine type and reel index.

\section{Effective field capacity}

As shown in Table 7, analysis of variance (ANOVA) of the data showed that reel index and the type of combine harvester were highly significant for field capacity $(\mathrm{P}<0.01)$. However, the interaction between combine harvester type and the reel index was significant at $5 \%$ level of significance, suggesting that at all three reel index levels and the type of combine harvester influenced the field capacity.

Table 7. ANOVA of combine capacity.

\begin{tabular}{lccccc}
\hline Source & $\begin{array}{c}\text { Type III } \\
\text { sums of } \\
\text { squares }\end{array}$ & $\begin{array}{c}\text { Degrees of } \\
\text { freedom }\end{array}$ & Means square & F value & P value \\
\hline Replicate & 0.04289 & 2 & 0.02144 & 23.15 & 0.0005 \\
Combine type (CT) & 0.08446 & 1 & 0.08446 & 91.17 & $<0.0001$ \\
Reel index (RI) & 0.02355 & 2 & 0.01177 & 12.71 & 0.0033 \\
CT x RI & 0.01076 & 2 & 0.00538 & 5.81 & 0.0277 \\
\hline
\end{tabular}

\section{Field efficiency}

Anova showed that the efficiency was influenced by the combine type and reel index at $1 \%$ level of significance. However, the interaction between combine harvester type and the reel index was significant at 5\% level of significance, suggesting that at all three reel index levels and the type of combine harvester had an effect on the field efficiency (Table 8). 
Table 8. ANOVA of field efficiency.

\begin{tabular}{lccccc}
\hline \multicolumn{1}{c}{ Source } & $\begin{array}{c}\text { Type III } \\
\text { sums } \\
\text { of squares }\end{array}$ & $\begin{array}{c}\text { Degrees of } \\
\text { freedom }\end{array}$ & Means square & F value & P value \\
\hline Replicate & 0.1278 & 2 & 0.0639 & 128.18 & $<0.0001$ \\
Combine type (CT) & 0.1002 & 1 & 0.1002 & 200.86 & $<0.0001$ \\
Reel index (RI) & 0.0783 & 2 & 0.0391 & 78.52 & $<0.0001$ \\
CT x RI & 0.0072 & 2 & 0.0036 & 7.31 & 0.0157 \\
\hline
\end{tabular}

\section{Performance of combines}

The effect of reel index on field efficiency of Kubota was significantly influenced by the combine type but the field capacity was not influenced by any level of reel index in both combine harvesters. Even though the field efficiency was significantly higher at reel indices 1.2 and 1.7, it was not significantly different between reel indices 1.2 and 1.7 in Kubota. But, the field efficiency was significantly lower at the reel index of 2.5 in both Kubota as well as in Agroworld combine harvesters. As far as the Agroworld combine harvester is concerned, the field efficiency was significantly higher at the reel index of 1.2 and it was different from all the three levels of reel indices (Table 9).

Table 9. Effect of combine type and reel index on combine capacity and field efficiency.

\begin{tabular}{lccc}
\hline $\begin{array}{l}\text { Main factor } \\
\text { (harvester type) }\end{array}$ & $\begin{array}{l}\text { Sub factor (reel } \\
\text { index) }\end{array}$ & Actual field capacity & Field efficiency \\
\hline \multirow{3}{*}{ Kubota } & 1.2 & $0.39^{\mathrm{a}}$ & $0.604^{\mathrm{a}}$ \\
& 1.7 & $0.33^{\mathrm{ab}}$ & $0.584^{\mathrm{a}}$ \\
& 2.5 & $0.24^{\mathbf{b}}$ & $0.495^{\mathbf{b}}$ \\
\hline \multirow{3}{*}{ Agroworld } & 1.2 & $0.19^{\mathrm{a}}$ & $0.508^{\mathbf{a}}$ \\
& 1.7 & $0.19^{\mathrm{a}}$ & $0.426^{\mathbf{b}}$ \\
& 2.5 & $0.16^{\mathbf{a}}$ & $0.301^{\mathbf{c}}$ \\
\hline
\end{tabular}

Means denoted by the same letter are not significantly different at $P=0.05$

\section{CONCLUSIONS}

The header advancement per radian of reel rotation was greater at the reel index 1.2, which has resulted in poor crop gathering capacity in both types of combine harvesters. However, less advancement of header at the reel index of 2.5 resulted in an increased crop gathering capacity as well as increased number of impacts on the panicles. Consequently, the header losses were found to be higher at the reel indices of 1.2 and 2.5 for both combine harvesters.

A greater tine bar velocity of $2.51 \mathrm{~m} / \mathrm{s}$ and $2.33 \mathrm{~m} / \mathrm{s}$ resulted in higher header losses from Kubota and Agroworld combine harvesters, respectively at the reel index of 1.2. Also, increased number of impacts contributed to higher header losses at the reel index of 2.5. The reel index of 1.7 resulted in a significantly $(P<0.05)$ lower header losses of $38.8 \mathrm{~kg} / \mathrm{ha}$ and $45.8 \mathrm{~kg} / \mathrm{ha}$ in Kubota and Agroworld combine harvesters, respectively. 
The actual field capacities decreased from $0.380 \mathrm{ha} / \mathrm{h}$ to $0.245 \mathrm{ha} / \mathrm{h}$ for Kubota, whereas, the decrease was $0.197 \mathrm{ha} / \mathrm{h}$ to $0.175 \mathrm{ha} / \mathrm{h}$ for Agroworld, across the reel indices tested from 1.2 to 2.5. However, the field efficiency increased from $49.3 \%$ to $60.9 \%$ for Kubota and $30.6 \%$ to $50.8 \%$ for Agroworld across the reel indices of 1.2 to 2.5. The field efficiency was significantly higher at the reel index of 1.2 and 1.7 in Kubota whereas it was significantly higher at 1.2 in Agroworld. However, the field efficiency was significantly lower at reel index 2.5 in both Kubota and Agroworld combine harvesters.

Therefore, it can be recommended that reel index of 1.7 would be ideal in terms of minimum header losses as well as acceptable field capacities and field efficiencies. This implies that forward speeds of $0.82 \mathrm{~m} / \mathrm{s}(2.95 \mathrm{~km} / \mathrm{h})$ for Kubota and $0.76 \mathrm{~m} / \mathrm{s}(2.73 \mathrm{~km} / \mathrm{h})$ for Agroworld at the reel angular velocity of $30 \mathrm{rpm}$ can be recommended for harvesting $B G$ 94-1 paddy variety.

\section{REFERENCES}

Chinsuwan, W., Mongpraneet, S. and Panya, N. (1997). Optimum harvest period for Hommali rice using combine harvester. KKU Research Journal. 2(1), 54-63.

Chinsuwan, W., Pongjan, N., Chuan-Udom, S., and Phayom, W. (2004). Effects of reel index on gathering loss of rice combine harvester. Thai Society of Agricultural Engineering Journal (TSAE Journal). 1(1), 7-9.

El-Shal, M.S. and Morad, M.M. (1991). Improving the combine header performance in respect to rice grain losses. Misr J. Agric. Eng. 8(1), 1-10.

Goryachkin, V.P. (1974). Collected works in three volumes, Vol III. Springfield, Virginia 22151, U.S. Department of Commerce, National Technical Information Service in Oduori, M.F., Mbuya, T.O., Sakai, J. and Inoue, E. (2008). Shattered rice grain loss attributable to the combine harvester reel: Model formulation and fitting to field data. Agric. Eng. Int.: The CIGR E Journal, 10.

Griffin, G.A. (1976). Fundamentals of Machine Operations Combine Harvesting. John-Deere service publication. pp 145-149.

Hashish, A.I. (1984). Rice combine harvesting parameters. J. Agric. Res. Tanta University 10(3), 736 .

Hassan, M.A., Morad, M.M., El-Shazly, M.A. and Farag, A. (1994). Study on some operating parameters affecting the performance of combine devices with reference to grain losses. Misr. J. Agric. Eng. 11(3), 764-780.

Helmy, M.A., Gomaa, S.M., Hindey, F.I. and Abushieshaa, R.R. (1995).Comparative study on two different rice combine harvesting machine. Misr. J. Agric. Eng. 12(2), 479-495.

Junsiri, C. and Chinsuwan, W. (2009). Operating parameters affecting header losses of combine harvesters for Chainat 1 rice variety. KKU Research Journal. 14(3), 314-321.

Mahrouf, A.R.M. and Rafeek, M.I.M. (2010). Mechanization of paddy harvesting :An economic perspective, Socio Economic and planning center, Peradeniya, Sri Lanka. 
Oduori, M.F., Mbuya, T.O., Sakai, J. and Inoue, E. (2008). Shattered rice grain loss attributable to the combine harvester reel: Model formulation and fitting to field data. Agric. Eng. Int.: The CIGR E Journal, 10.

Oduori, M.F., Mbuya, T.O., Sakai, J. and Inoue, E. (2012). Kinematics of the tined combine harvester reel. Agric. Eng. Int. CIGR Journal. 14(3), 53-60.

RNAM (1995). Test Codes and Procedures for Agricultural Machinery. Technical Series 12. Regional Networks for Agricultural Machinery (RNAM) of the United Nations. Philippines. pp 207-225.

Samaraweera, G.C. (2012). Technological feasibility of using combine harvester in paddy cultivation in Sri Lanka - an economic and social perspective. International Journal of Research in Engineering, IT and Social Sciences. 2(9), 77-90.

Sial, J.K., Iqbal, M., Cheema, F., Sabir, M.S. and Mahmood, S. (1992). Shattering losses as affected by the combine indices. Pak. Journal of Agric. Sciences. 29(3), 241-245. 